\title{
Characterization and Phylogenetic Analysis of Soybean Rhizobial Strains from Java and Sumatra
}

\author{
SETIYO HADI WALUYO \\ Center for the Application of Isotopes and Radiation Technology, National Nuclear Energy Agency (BATAN), \\ Jalan Lebak Bulus Raya Pasar Jum'at, Jakarta 12070, Indonesia
}

\begin{abstract}
Twenty-seven and twenty-four soybean rhizobial isolates from Java and Sumatra, respectively,were characterized. Based on cross-inoculation, eight isolates from Java and nine from Sumatra could be grouped as soybean specific rhizobial species, while 19 isolates from Java and 15 from Sumatra were promiscuous. ARDRA of intergenic spacer region of 16S-23S rDNA showed that the isolates from Java were different from those from Sumatra. Six soybean specific isolates from Java and one from Sumatra were in the same cluster with the reference strain, Bradyrhizobium japonicum USDA 110, thus could be classified as B. japonicum. One soybean specific isolate from Java's has a distinct position, while the other soybean specific isolate from Java was placed in another group dominated by isolates from Sumatra. The nineteen promiscuous isolates from Java were clustered in a different group. This group, together with the isolate with distinct position and the other group that were dominated by isolates from Sumatra, were distinct from B. japonicum USDA 110. Therefore it is tempting to speculate that they represent indigenous soybean rhizobial strains. Based on complete sequencing of the amplified 16S rDNA of 21 selected isolates, these isolates could be divided into three groups consisting of twelve Bradyrhizobium elkanii, eight Bradyrizobium japonicum and one Sinorhizobium fredii. Most of the B. elkanii strains were isolated from acid soils at Sitiung, West-Sumatra, while only two isolates were obtained from Java. Four isolates from Java, two isolates from Sitiung, and two isolates from Bukit Tinggi were identified as B. japonicum. One isolate from Java with a distinct position on the ARDRA was identified as S. fredii.
\end{abstract}

Key words: Amplified Ribosomal DNA Restriction Analysis (ARDRA), cross-inoculation, rhizobia, soybean, sequencing

Dua puluh tujuh isolat bakteri rhizobia kedelai dari Jawa dan 24 isolat dari Sumatra telah diidentifikasi secara crossinoculation pada tanaman kedelai dan kacang hijau serta secara genetika molekuler(ARDRA dan pemetaan). Dengan metode "cross-inoculation", 8 isolat Jawa dan 9 isolat Sumatra dapat membentuk bintil akar efektif hanya pada tanaman kedelai (spesifik), sedangkan sisanya 19 isolat Jawa dan 15 isolat Sumatra dapat membentuk bintil akar efektif pada tanaman kedelai dan kacang hijau (promiscuous). Metode ARDRA dapat membedakan antara isolat dari Jawa dan Sumatra. Enam isolat Jawa dan tiga isolat Sumatra berada dalam satu grup dengan Bradyrhizobium japonicum USDA 110, dan diklasifikasikan sebagai B. japonicum. Satu isolat Jawa spesifik kedelai menempati posisi tersendiri, dan sisanya 1 isolat berada dalam grup yang didominasi oleh isolat-isolat Sumatra. Sembilan belas isolat Jawa promiscuous membentuk grup tersendiri, bersama dengan satu isolat yang posisinya distinct dan grup yang didominasi oleh isolat-isolat Sumatra. Grup ini berbeda nyata dengan Bradyrhizobium japonicum USDA 110. Oleh karena itu, diduga kuat bahwa isolat-isolat tersebut adalah bakteri rhizobia kedelai asli Indonesia. Pemetaan deret ribosomal DNA 16S dari 21 isolat pilihan menunjukkan bahwa isolat-isolat tersebut dapat dibagi menjadi tiga grup, yaitu grup Bradyrhizobium elkanii 12 isolat, grup Bradyrhizobium japonicum delapan isolat, dan satu isolat yang khusus tersebut masuk dalam grup Sinorhizobium fredii. Sebagian besar galur B. elkanii di peroleh dari tanah asam di Sitiung, Sumatra Barat. Hanya dua strain B. elkanii yang berasal dari tanah Jawa. Empat isolat Jawa, dua isolat Bukit Tinggi dan dua isolat Sitiung diidentifikasi sebagai B. japonicum. Satu isolat yang khusus diidentifikasi sebagai S. fredii.

Kata kunci:ARDRA, cross-inoculation, kedelai, rhizobia, sequencing

Leguminous plants nodulating bacteria were first described in 1888 (Beijerinck 1888) and their initial classification as rhizobia was based on their host range specificity. Their symbiotic relations with the host plants remains very important, since this is the most conspicuous feature of rhizobia and has an important practical value. However, the symbiotic and physiological properties of soybean nodulating rhizobia have been found to be more diverse than originally anticipated. The discovery of fast-growing soybean nodulating rhizobia belonging to the genus Sinorhizobium (Ensifer) (Keyser et al. 1982; Scholla

*Corresponding author, Phone : +62-21-7690709, Fax : +62-21-7513270, E-mail: shwaluyo@yahoo.com and Elkan 1984; Young 2003, Young 2010) underlines the need to consider the symbiotic properties, particularly since representatives of this genus often fail to nodulate modern soybean cultivars. In addition, there are some rhizobia outside the genus Bradyrhizobium and Sinorhizobium (Ensifer), now designated Mesorhizobium spp., that were reported to form nodules on soybean (Chen et al. 1995; Jarvis et al. 1997). The ambiguous results often found with hostrange nodulation tests have driven the development of DNA based determination techniques (Laguerre et al. 1994; Massol-Deya et al. 1995; Vandamme et al. 1996; Rademaker and De Bruijn 1997).

In recent years, other methods, including phenotypic traits, DNA:DNA relatedness and 
molecular techniques based on Polymerase Chain Reaction (PCR), have been included in rhizobial classification (Sikora and Redzepovic 2003; Kwon et al. 2005; El-Fiki 2006, Martens et al. 2007). Presently, there is a great variety of phenotypic and genotypic methods available that permit a different degree of phylogenetic classification varying from genus, species, subspecies, biovar to the strain level. However, the description of new genera and species of root-nodulating rhizobia should fulfill a minimal standard, as has been proposed by Graham et al (1991) and Novikova (1996). The development and implementation of these molecular techniques have accelerated the taxonomic evaluation of rhizobia. The current classification of rhizobia, which is mainly based on the nucleotide sequences of the small subunit ribosomal RNA (rRNA), are Rhizobium (Agrobacterium), Bradyrhizobium, Sinorhizobium (Ensifer), Mesorhizobium, Azorhizobium, Methylobacterium, Burkholderia, Cupriavidus, Devosia, Ochrobacterium, Phyllobacterium and Shinella (Hungria et al. 2006; Willems 2006; Raychaudhuri et al. 2007; Rivas et al. 2009, Lu et al. 2011).

The importance of rhizobial strains for soybean cultivation in Indonesia had already been shown since a long time ago (Toxopeus 1938). Meanwhile, the taxonomy of Bradyrhizobium and Sinorhizobium genera is of particular interest as they consist of strains known to nodulate soybean, which is an important food crop. Most of soybean nodulating rhizobial strains from the primary gene centers for soybean in China or Japan have been well studied and characterised. However, while Indonesia is supposed to be a second gene-centre of soybean plants, (Hymowitz and Newell 1981) there is only a limited information on the diversity of rhizobial strains from Indonesia.

There is a general lack of information on the population structure of the indigenous soybean rhizobia native to Indonesian soils. However, insight in the structure of indigenous soybean rhizobia populations is one of the important aspects for the success of Biological Nitrogen Fixation (BNF). Particularly in the areas where indigenous rhizobia are present abundantly (Saono 1988). As a consequence, a thorough survey is needed to study the occurrence of the bacteria in different locations in Indonesia. Furthermore, it is essential to characterise the isolates using reliable molecular methods. It opens the possibility to select elite indigenous soybean rhizobia under favourable conditions, such as those in Java, where they are abundantly present in most soils. In addition, under acidic condition such as in Sumatra, where the condition is unfavourable for rhizobia, the survey may be important to select rhizobial strains that are well adapted to stress conditions.

In this study, therefore, a comparison was made between indigenous soybean rhizobia isolated from traditional soybean areas in Java and a variety of soils in Sumatra. The bacterial isolates were characterised for their symbiotic properties and classified based on Amplified Ribosomal DNA Restriction Analysis (ARDRA) of PCR-amplified 16S rDNA and 16S-23S rDNA intergenic spacer region. A selected number of isolates were characterised in more detail by the amplification, cloning, and sequence analysis of the major part of their 16S rDNAgenes.

\section{MATERIALS AND METHODS}

Rhizobial Strains and Media. Fifty-one soybean rhizobial isolates from Java and Sumatra, B. japonicum USDA 110 and CB1809 and Bradyrhizobium spp. CB756 (obtained from the Laboratory of Microbiology, Wageningen University, Netherlands) were maintained in Yeast Extract Mannitol Broth (YEMB) solidified with $1.0 \%$ agar and grown for inoculum preparation in YEMB at $30{ }^{\circ} \mathrm{C}$ for 4 - 7 days (Somasegaran and Hoben 1995).

To obtain indigenous soybean nodulating rhizobial strains, local varieties of soybean seeds (Glycine max cv. Tidar) obtained from the Bogor Research Centre for Food Crops, Bogor, Indonesia and mungbean (Vigna radiata $\mathrm{cv}$. Manyar) seeds obtained from the Centre for the Application of Isotopes and Radiation Technology, National Nuclear Energy Agency, Jakarta, Indonesia were used to study the host specificity of the isolates.

Agronomic Analysis. To characterize the symbiotic properties, the rhizobial isolates were used to inoculate soybean and mungbean plants grown on a modified Hoagland-N free medium as described previously (Winarno and Lie 1979). Plants were harvested 20 days after inoculation. Colour and weight of shoots, as well as weight and number of nodules were determined. The capacity to fix $\mathrm{N}$ was deduced by comparing the colour and weight of the control and inoculated plants, all were grown in a $\mathrm{N}$-free medium.

Genetic Analysis. Genomic DNA to be used as template for PCR amplification of the 16S rRNA gene and the 16S-23S rRNA intergenic spacer regions was extracted from YEMB-grown bacterial cells as follows. Four $\mathrm{ml}$ of bacterial culture containing $10^{9} \mathrm{cfu}$ $\mathrm{ml}^{-1}$ was harvested by centrifugation and suspended in $450 \mu \mathrm{L}$ TE buffer (1 mM Tris-HCl, 0.1 mM EDTA, pH 7.4), containing $0.5 \%$ SDS, followed by incubation at $37^{\circ} \mathrm{C}$ with gentle shaking for 30 minutes. DNA was extracted by the addition of an equal volume of phenol 
buffered in $10 \mathrm{mM}$ Tris- $\mathrm{HCl}$ and $1 \mathrm{mM}$ EDTA, $\mathrm{pH} 7.0$ to the mixture. This extraction was repeated once using an equal volume of phenol and chloroform mixture. Subsequently, nucleic acid was precipitated by the addition of equal volume of ethanol $90 \%\left(-20^{\circ} \mathrm{C}\right)$ and $10 \%$ volume of sodium acetate $(3 \mathrm{M}, \mathrm{pH} 5.2)$. The precipitate was collected by centrifugation, dried and dissolved in $50 \mu \mathrm{L}$ sterile water. The amount of the isolated DNA was determined by electrophoresis on a $1 \%$ agarose gel containing ethidium bromide with $0.1 \mathrm{~g}$ of DNA digested with HindIII (GibcoBRL LifeTechnology, Breda, Netherlands) as a reference. Ribosomal DNA fragments were amplified using a set of primers as described previously, primer $8 \mathrm{f}$ [ 5'-CAC GGA TCC AGA GTT TGAT (C/T) (A/C) TAG TCC AG-3'] an primer 1510r [5'-GTT AA GTT ACTG (C/T) TAC GTT GTT ACG ACTT-3'] for 16S rDNA PCR reaction (Lane 1991; Laguerre et al. 1994) and primer pHr [5'-TGCGGCTGGATCACCTCCTT-3'] and primer p23SROI [5'-GGCTGCTTCTAAGCCAAC3'] for 16S-23S rDNA intergenic spacer PCR reaction (Massol-Deya et al. 1995). DNA amplification using approximately $50 \mathrm{ng}$ of genomic DNA as a template in a 1001 PCR reaction volume was performed using a UNOII Thermocycler, Biometra, Göttingen, Germany as described previously (Massol-Deya et al. 1995).

The size and amount of the amplified DNA was examined by electrophoresing $5.0 \mu \mathrm{L}$ of PCR product on a $0.7 \%$ agarose gel containing ethidium bromide and DNA digested with HindIII as a reference. Approximately $400 \mathrm{ng}$ of the amplified DNA was digested using restriction endonucleases CfoI, DdeI, HaeIII, and $M s p \mathrm{I}$ (5 units per $25 \mu \mathrm{L}$ reaction) following instruction of the manufacturer (GibcoBRL LifeTechnology, Breda, The Netherlands) and the generated fragments were separated by electrophoresis on $3 \%$ agarose gels containing ethidium bromide at 100 $\mathrm{V}$ for 2 hours. ARDRA fingerprints of $16 \mathrm{~S} \mathrm{rDNA}$ and 23S-16S rDNA (intergenic spacer region) PCRproducts were recorded as TIFF files, analysed and used to prepare a dendogram based on predictions by Unweighted Pair Group Method using Arithmetic averages (UPGMA) by Molecular Analysist Software (BioRad 1995).

Cloning of the 16S rDNA PCR Products and Plasmid DNA Isolation. Based on the effectiveness and the efficiency of the soybean nodulating rhizobia strains in biological nitrogen fixation of soybean, seven isolates from Java and 14 isolates from Sumatra were chosen for further examination by $16 \mathrm{~S}$ rDNA sequencing. The $16 \mathrm{~S}$ rDNA PCR products from the selected strains, were purified using Qiaquick PCR purification kit following instructions of the manufacturer (Qiagen, Hilden, Germany), and were quantified by electrophoresis on $1.2 \%$ agarose gel with known amount of DNA digested with HindIII as a standard (GibcoBRL Life Technology, Breda, Netherlands). Then the PCR-amplified 16S rDNA fragments were cloned in Escherichia coli JM109 using the $\mathrm{pGEM}^{\mathrm{R}}-\mathrm{T}$ Vector system following a procedure provided by the supplier (Promega, Leiden, Netherlands). For plasmid DNA isolation, one colony of ampicillin-resistant transformant was used to inoculate to Luria-Bertani (LB) broth medium containing ampicillin $\left(100 \mathrm{~g} \mathrm{~mL}^{-1}\right)$, and incubated at $37{ }^{\circ} \mathrm{C}$ for 24 hours (Manniatis et al. 1982). Plasmid DNA was isolated using a column Wizard $^{\mathrm{TM}}$ Plus Minipreps DNA Purification System (Promega, Leiden, Netherlands). Purified plasmid DNA was quantified by electrophoresis on a $1.2 \%$ agarose gel with known amount of DNA digested with HindIII as a standard (GibcoBRL Life Technology, Breda, Netherlands).

Sequence Analysis. The purified plasmid DNA (250 ng) was used as template for sequencing reaction. Infrared-labelled primers were used for reaction, for the forward reaction primer SP6 IRD800 (5' -GAT TTA GGT GAC ACT ATA G-3') and for the reverse reaction primer T7 IRD800 (5'- TAA TAC GAC TCACTA TAG GG-3')(MWG Biotech, Ebersberg, Germany). PCR sequencing reactions were performed with reagents provided by the supplier (Amersham Pharmacia Biotech, Freiburg, Germany) and the following temperature setting: $93{ }^{\circ} \mathrm{C}$ for 3 minutes; 30 cycles of $93{ }^{\circ} \mathrm{C}$ for 30 seconds, $45^{\circ} \mathrm{C}$ for 30 seconds, $70{ }^{\circ} \mathrm{C}$ for 15 seconds; and storage at $4{ }^{\circ} \mathrm{C}$. The products were separated and analysed on a Li-Cor DNA sequencer 4000L (LiCor, Lincoln, Nebraska, USA). Before loading the samples $(1.8 \mu \mathrm{L})$, the gel was pre-run for 30 minutes at $1000 \mathrm{~V}$. After loading samples, electrophoresis was carried out at $1000 \mathrm{~V}$ constant voltage while the gel was heated at $50{ }^{\circ} \mathrm{C}$. The sequences of approximately 1000-1200 nucleotides both in the forward and reverse directions were obtained, corrected manually, and combined into a single contig of 1200 - 1500 of unambiguous sequence by using SeqMan II DNA Star Software (DNASTAR Inc., Madison, Wisconsin, USA).

Identification of the Soybean Rhizobia on the Basis of 16S rDNA Homology. The obtained 16S rDNA sequence data were analysed for their homology with the blastn program from The GenBank Network (http://www.ncbi.nlm.nih.gov/cgi-bin/BLAST/). A rooted phylogenetic tree (neighbour joining) was calculated using the programmes and database from Ribosomal RNA Alignment (ARB), an environment 
for $16 \mathrm{~S} / 18 \mathrm{~S} / 23 \mathrm{~S}$ ribosomal RNA sequence data, and E. coli position 150 - 1114 (Felsenstein correction). The ARB Package is a software containing combination of alignment and dendrogram tools, allowing alignment to a comprehensive 16S rDNA database and detailed phylogenetic analysis.

\section{RESULTS}

Agronomic Aspects. In general, rhizobial strains obtained from Java were as effective as the soybeannodulating reference strains $B$. japonicum USDA 110 and CB 1809. The number of nodules were 43, 29, and 46 for B. japonicum USDA 110, CB 1809 and isolates from Java, respectively, while the total weights of nodules were $0.288,0.25$, and $0.263 \mathrm{~g}$ for B. japonicum USDA 110, CB 1809 and isolates from Java, respectively. The average shoot weight of soybean inoculated with B. japonicum USDA 110, CB 1809 and isolates from Java were $3.36,3.7$, and $3.75 \mathrm{~g}$, respectively. On the other hand, the average number and weight of nodules, as well as shoots weight, of plants inoculated with the rhizobial strains from Sumatra were $37,0.225$, and $2.43 \mathrm{~g}$, respectively. This is significantly lower than those from Java. The difference was most significant in the weight of shoots $(=0.01$, MSTAT-C 1988, Table 3$)$. It was observed that the first two leaves of all soybean plants inoculated with rhizobial isolates from Sumatra were yellow and in most cases were lost very quickly, indicating poor $\mathrm{N}$ fixing capacity.

The ability of the isolated rhizobial strains to form nodule on mungbean plant was also tested (Fig 1). This analysis revealed that most of the strains from both Java and Sumatra showed promiscuous nodulation properties that were not observed with the well-known inoculant strains of B. japonicum USDA
110 and CB 1809.

Amplified Ribosomal (16S and 16S-23S) DNA Restriction Analysis (ARDRA). Genomic DNA of the isolated rhizobial strains (27 from Java and 24 from Sumatra) and that of the reference strain $B$. japonicum USDA 110 were isolated and used as templates for PCR amplifications of the 16S rDNA and the 16S-23S rDNAs spacer regions (Fig 1). The amplified 16S rDNA's all showed the expected size of approximately $1.6 \mathrm{~kb}$ and upon digestion with four different restriction enzymes ( $C f o \mathrm{I}$, Dde I, HaeIII and $M s p I$ ) a variety (up to 19) of restriction length polymorphism patterns were observed. This ARDRA approach allowed the grouping of the rhizobial isolates into two main clusters, while Java isolate J-TGS50 and Sumatra isolates S-ST123 and S- ST414 showed rather unique position (Fig 2).

One cluster consists of most (25) of the rhizobial isolates from Java, four isolates from Sumatra and also B. japonicum USDA 110. The other cluster consists of most (18) of the rhizobial isolates from Sumatra and only one strain isolated from Java (J-YG49). Both clusters contained isolates that showed only nodulation of soybean as well as ones with promiscuous nodulation properties.

The PCR products of the 16S-23S spacer rDNA were all of the same size of approximately $2 \mathrm{~kb}$. Differentiation of these 16S-23S rDNA amplicons by ARDRA using the same restriction enzymes as used for the 16S rDNA amplicons, revealed that these large DNA fragments showed significant sequence variations (Fig 3, Fig 4, Fig 5, Fig 6).

Twenty-seven composite restriction pattern types were obtained by combining data from the digestion patterns (Table 1). DdeI was the most discriminating enzyme, with twenty-one (21) genotypes detected

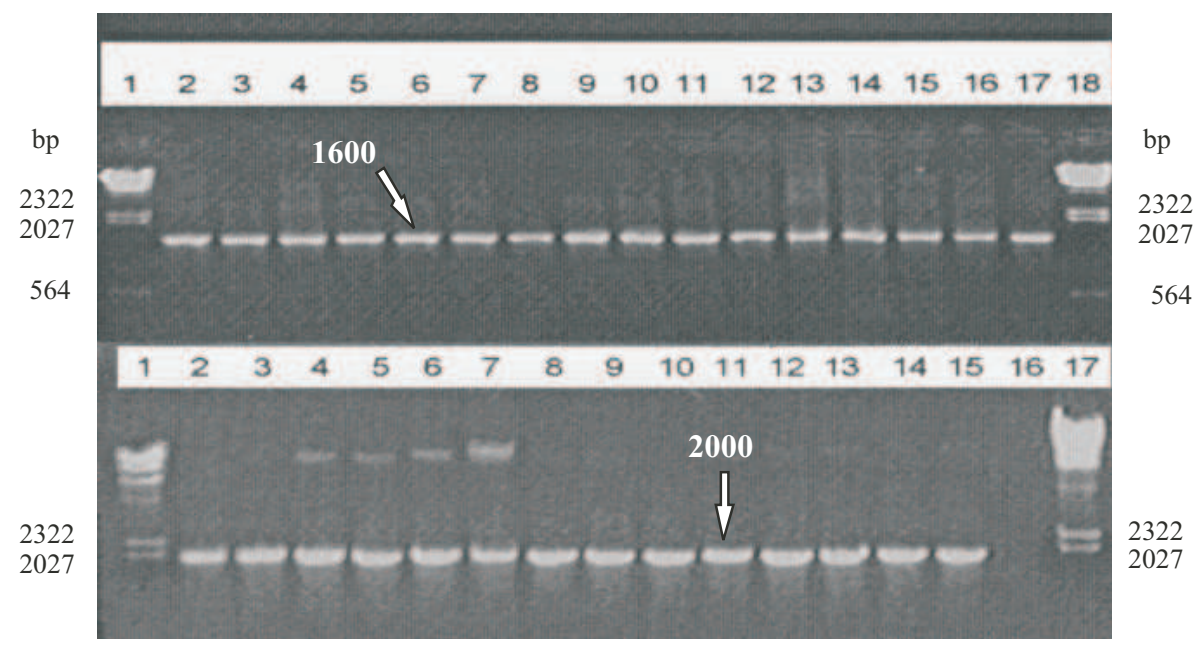

Fig 1 16S rDNA (above) and 16S-23S rDNA (below) PCR-products. 


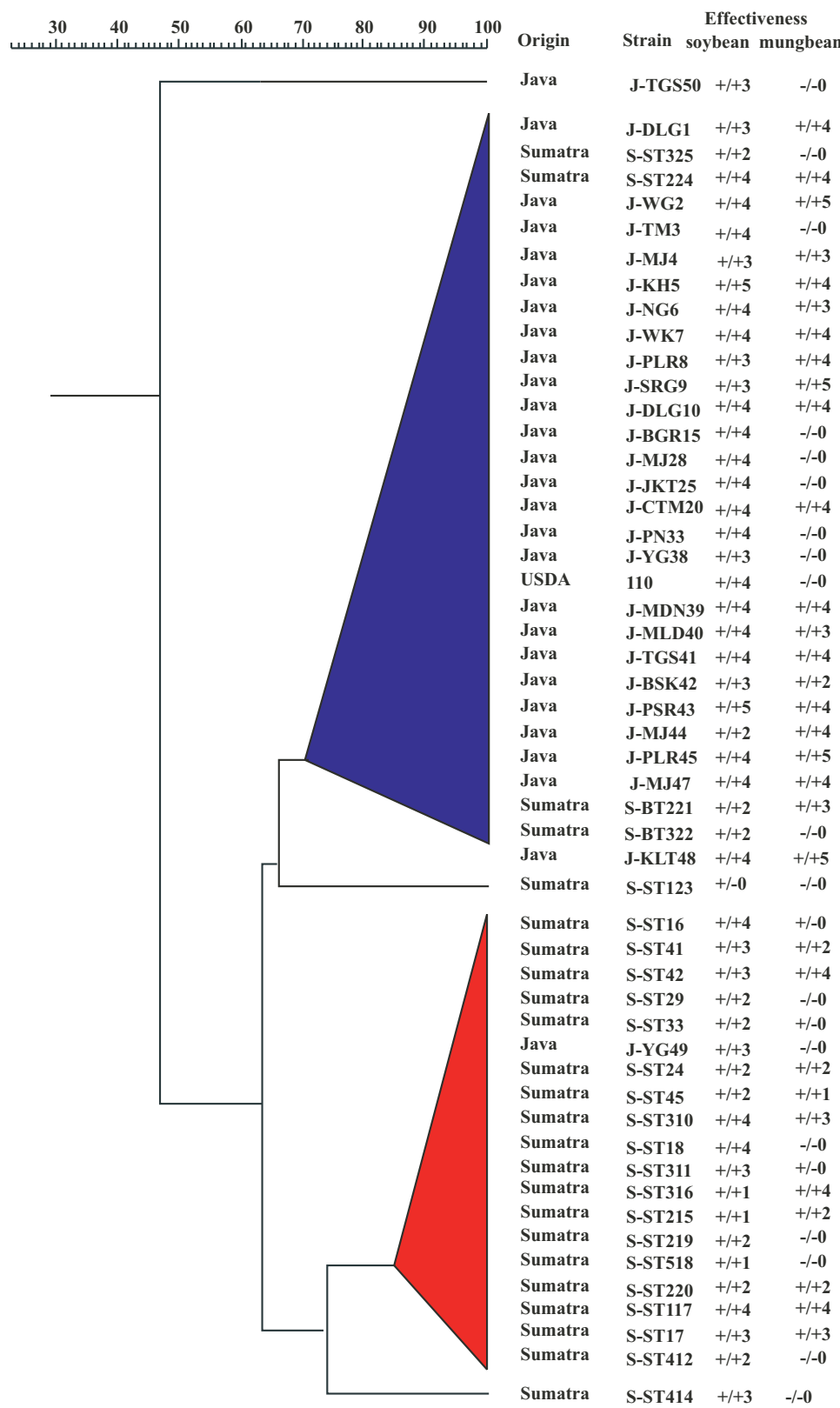

Fig 2 Dendogram derived from 16S rDNA ARDRA fingerprints and symbiotic properties of rhizobial strains isolated from Java and Sumatra soil samples as well as B.japonicum USDA 110.+/+, nodulating and N-fixing; +/-, nodulated and no $\mathrm{N}$-fixed; -/-, not nodulated and no N-fixed. The effectiveness of $\mathrm{N}$ fixation is indicated by values ranging from 1 (ineffective) to 5 (effective).

among the rhizobial isolates. Based on these complex ARDRA fingerprints, the rhizobial isolates were grouped into four main clusters (Fig 7).

All strains isolated from Java, except for J-YG49, could be grouped into two clusters, one includes $B$. japonicum USDA 110. Again the Java isolate J-TGS50 showed a unique position. Similarly, all strains isolated from Sumatra, except for strains S-ST224, S-ST325 and S-ST123, could be grouped in one very large cluster, while two strains (S-BT221 and S-BT322) formed a cluster that was distantly related to that of B. japonicum USDA 110.

The obtained 16S rDNA sequences of 21 selected, soybean-nodulating rhizobial strains from those
Indonesian isolates were compared to those of reference strains obtained from the GenBank and ARB databases (Table 2). The high homology of the rDNA sequences indicated that all the isolates, except for J-TGS50, could be assigned to genus Bradyrhizobium and are related to either B. elkanii or B. japonicum (Table 2). Strain TGS50, the unique isolate from Java, was found to belong to genus Sinorhizobium and its $16 \mathrm{~S}$ rDNA sequence showed $97.7 \%$ homology to that of $S$. fredii. A rooted phylogenetic tree was constructed,showing that all rhizobial isolates from Java and Sumatra, except for strain J-TGS50, could be grouped into 2 species, $B$. elkanii and B.japonicum (Fig 8). 


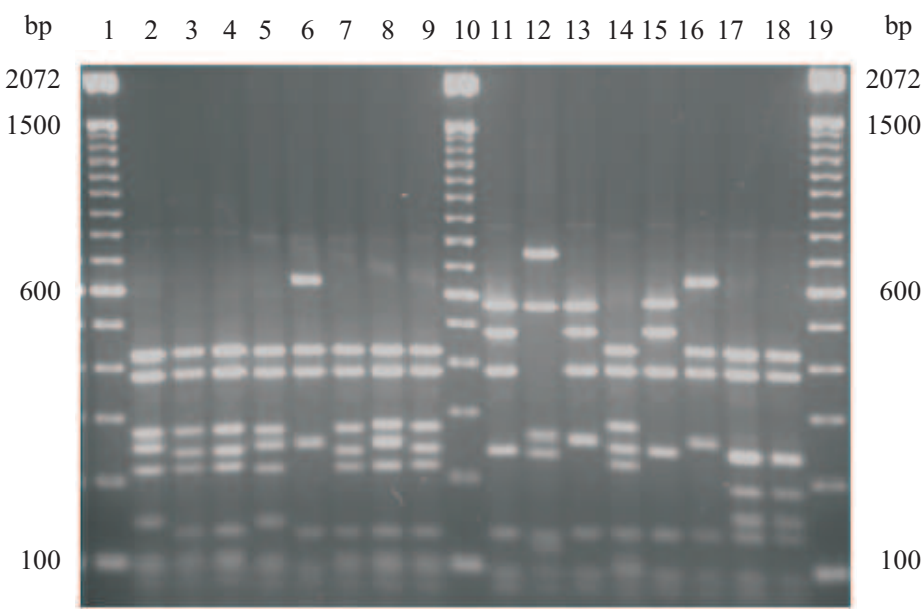

Fig 3 Restriction patterns of PCR-amplified fragments of 16S-23S rDNA intergenic spacer digested with MspI. Lanes 1, 10 and 19 are 100 bp DNA ladder (Life Technology). Lanes 2-9 (S-ST16; S-ST41; S-ST42; S-ST29; S-ST224; S-ST33; S-ST24; S-ST45) were derived from rhizobial isolates from Sumatra. Lanes 11-18 (J-MDN39; J-TGS50; J-BSK42; J-YG49; J-KLT48; J-KH5; J-MLD40; J-PSR43) were derived from rhizobial isolates from Java.

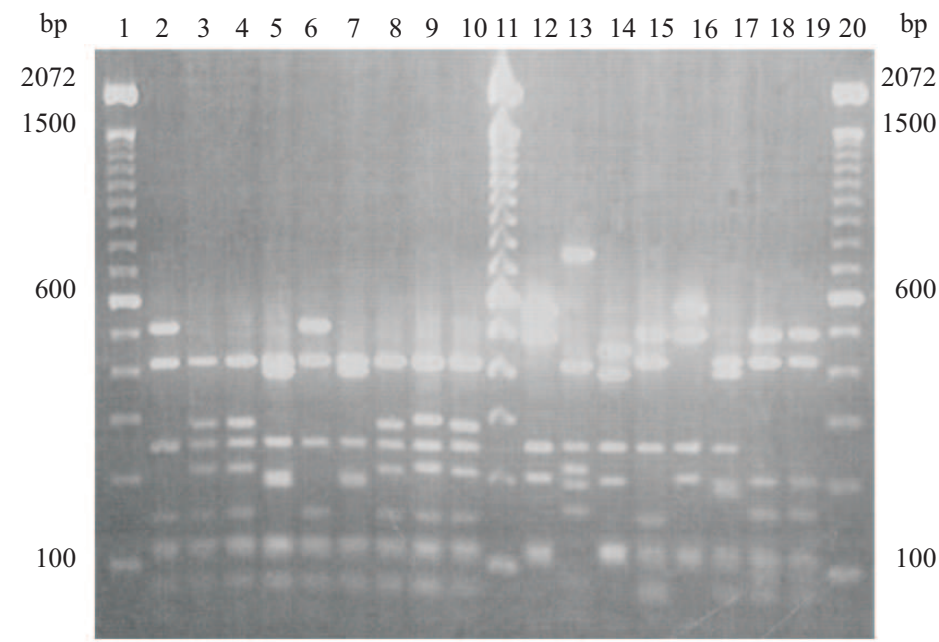

Fig 4 Restriction patterns of PCR-amplified fragments of 16S-23S rDNA intergenic spacer digested with DdeI. Lanes 1, 11 and 20 are 100 bp DNA ladder (Life Technology). Lanes 2-10 (S-ST16; S-ST41; S-ST42; S-ST29; S-ST224; S-ST33; S-ST24; S-ST45; S-ST311) were derived from rhizobial isolates from Sumatra. Lanes 12-19 (J-MDN39; J-TGS50; J-BSK42; J-YG49; J-KLT48; J-KH5; J-MLD40; J-PSR43) were derived from rhizobial isolates from Java.

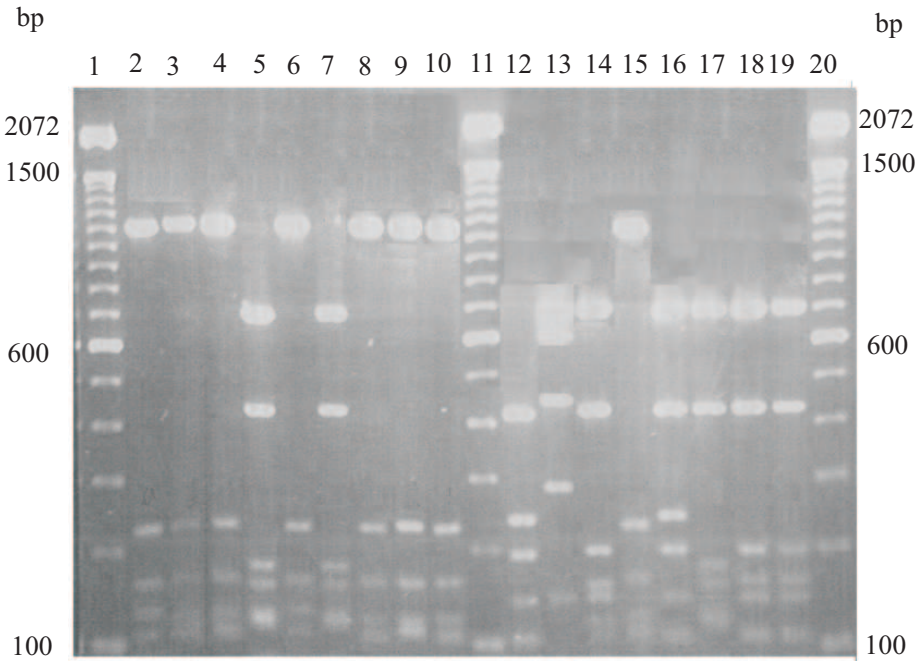

Fig 5 Restriction patterns of PCR-amplified fragments of 16S-23S rDNA intergenic spacer digested with CfoI. Lanes 1, 11 and 20 are 100 bp DNA ladder (Life Technology). Lanes 2-10 (S-ST16; S-ST41; S-ST42; S-ST29; S-ST224; S-ST33; S-ST24; S-ST45, S-ST311) were derived from rhizobial isolates from Sumatra. Lanes 12-19 (J-MDN39; J-TGS50; J-BSK42; J-YG49; J-KLT48; J-KH5; J-MLD40; J-PSR43) were derived from rhizobial isolates from Java 


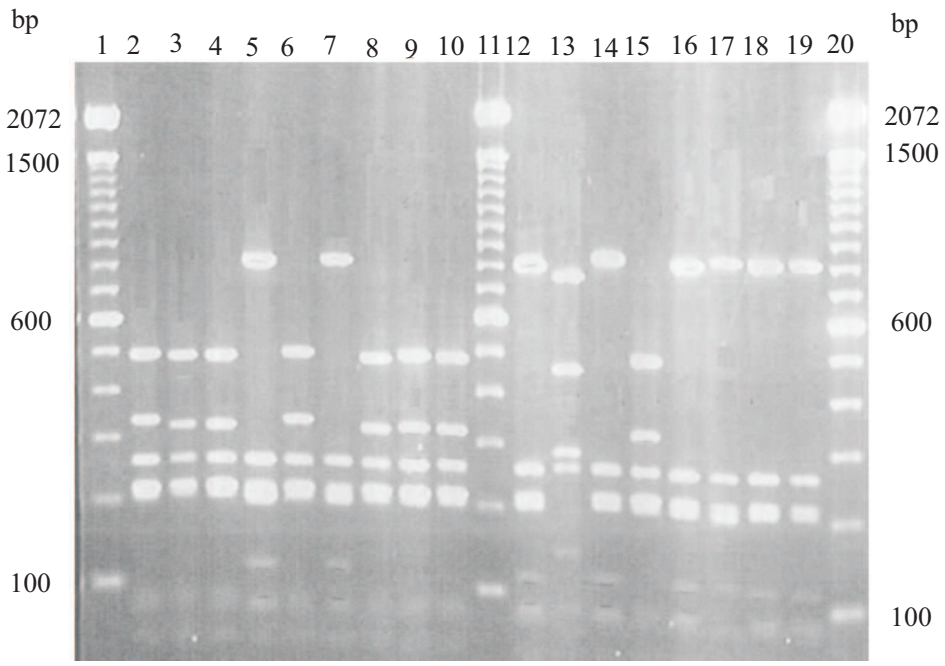

Fig 6 Restriction patterns of PCR-amplified fragments of 16S-23S rDNA intergenic spacer digested with HaeI. Lanes 1, 11 and 20 are 100 bp DNA ladder (Life Technology). Lanes 2-10 (S-ST16; S-ST41; S-ST42; S-ST29; S-ST224; S-ST33; S-ST24; S-ST45; S-ST311) were derived from rhizobial isolates from Sumatra. Lanes 12-19 (J-MDN39; J-TGS50; J-BSK42; J-YG49; J-KLT48; J-KH5; J-MLD40; J-PSR43) were derived from rhizobial isolates from Java.

Table 1 16S-23S rDNA genotypes and restriction patterns of the isolated rhizobial strains revealed by ARDRA

\begin{tabular}{|c|c|c|c|c|c|}
\hline \multirow[t]{2}{*}{ Isolate } & \multirow[t]{2}{*}{ 16S-23S r DNA genotype } & \multicolumn{4}{|c|}{ Restriction pattern of amplified 16S-23S rDNA digested with } \\
\hline & & $M s p \mathrm{I}$ & $D d e \mathrm{I}$ & HaeIII & $C f o l$ \\
\hline S-ST16 & I & $a^{*}$ & $\mathrm{a}$ & $\mathrm{a}$ & $\mathrm{a}$ \\
\hline S-ST29 & & $\mathrm{a}$ & $\mathrm{a}$ & $\mathrm{a}$ & $\mathrm{a}$ \\
\hline S-ST18 & II & $\mathrm{a}$ & $\mathrm{h}$ & $\mathrm{a}$ & $\mathrm{a}$ \\
\hline S-ST215 & III & $\mathrm{a}$ & $q$ & $\mathrm{a}$ & $\mathrm{h}$ \\
\hline S-ST41 & & $\mathrm{b}$ & $\mathrm{b}$ & $\mathrm{b}$ & $\mathrm{a}$ \\
\hline S-ST42 & & $\mathrm{b}$ & $\mathrm{b}$ & $\mathrm{b}$ & $\mathrm{a}$ \\
\hline S-ST45 & IV & b & $\mathrm{b}$ & $\mathrm{b}$ & $\mathrm{a}$ \\
\hline S-ST33 & & b & $\mathrm{b}$ & $\mathrm{b}$ & $\mathrm{a}$ \\
\hline S-ST311 & & $\mathrm{b}$ & $\mathrm{b}$ & $\mathrm{b}$ & $\mathrm{a}$ \\
\hline S-ST117 & & $\mathrm{b}$ & $\mathrm{b}$ & $\mathrm{b}$ & $\mathrm{a}$ \\
\hline S-ST17 & & b & $\mathrm{b}$ & $\mathrm{b}$ & $\mathrm{a}$ \\
\hline J-YG49 & V & $\mathrm{b}$ & $\mathrm{a}$ & $\mathrm{b}$ & $\mathrm{a}$ \\
\hline S-ST224 & & $\mathrm{c}$ & $\mathrm{c}$ & $\mathrm{c}$ & $\mathrm{c}$ \\
\hline J-WG2 & & $\mathrm{c}$ & $\mathrm{c}$ & $\mathrm{c}$ & $\mathrm{c}$ \\
\hline J-NG6 & & $\mathrm{c}$ & $\mathrm{c}$ & $\mathrm{c}$ & $\mathrm{c}$ \\
\hline J-WK7 & VII & $\mathrm{c}$ & $\mathrm{c}$ & $\mathrm{c}$ & $\mathrm{c}$ \\
\hline J-PLR8 & & $\mathrm{c}$ & $\mathrm{c}$ & $\mathrm{c}$ & $\mathrm{c}$ \\
\hline J-KH5 & & $\mathrm{c}$ & $\mathrm{c}$ & $\mathrm{c}$ & $\mathrm{c}$ \\
\hline J-DLG10 & & $\mathrm{c}$ & $\mathrm{c}$ & $\mathrm{c}$ & $\mathrm{c}$ \\
\hline J-DLG1 & & $\mathrm{c}$ & $\mathrm{c}$ & $\mathrm{c}$ & $\mathrm{c}$ \\
\hline J-SRG9 & & $\mathrm{c}$ & $\mathrm{c}$ & $\mathrm{c}$ & $\mathrm{c}$ \\
\hline S-ST24 & VIII & d & $\mathrm{d}$ & $\mathrm{a}$ & $\mathrm{d}$ \\
\hline S-ST310 & IX & d & $\mathrm{k}$ & $\mathrm{b}$ & $\mathrm{i}$ \\
\hline S-ST412 & $X$ & $\mathrm{~d}$ & $\mathrm{k}$ & $\mathrm{b}$ & $\mathrm{p}$ \\
\hline J-MJ44 & & $\mathrm{e}$ & $\mathrm{e}$ & $\mathrm{c}$ & $\mathrm{e}$ \\
\hline J-PLR45 & & $\mathrm{e}$ & e & $\mathrm{c}$ & $\mathrm{e}$ \\
\hline J-BSK42 & XII & e & $\mathrm{n}$ & $\mathrm{c}$ & $\mathrm{g}$ \\
\hline S-ST220 & XIII & $\mathrm{e}$ & $\mathrm{p}$ & $\mathrm{h}$ & $\mathrm{m}$ \\
\hline J-TGS50 & XIV & $\mathrm{f}$ & f & $\mathrm{d}$ & $\mathrm{f}$ \\
\hline J-MLD40 & & g & g & $\mathrm{c}$ & g \\
\hline J-TGS41 & $X V$ & $\mathrm{~g}$ & $\mathrm{~g}$ & $\mathrm{c}$ & $\mathrm{g}$ \\
\hline
\end{tabular}


Table 1 Continued

\begin{tabular}{|c|c|c|c|c|c|}
\hline \multirow{2}{*}{ Isolate } & \multirow{2}{*}{ 16S-23S r DNA genotype } & \multicolumn{4}{|c|}{ Restriction pattern of amplified 16S-23S rDNA digested with } \\
\hline & & MspI & DdeI & HaeIII & $C f o \mathrm{I}$ \\
\hline J-PSR43 & & $\mathrm{g}$ & $\mathrm{g}$ & $\mathrm{c}$ & $\mathrm{g}$ \\
\hline S-ST518 & $\mathrm{XVI}$ & $\mathrm{h}$ & $\mathrm{i}$ & $\mathrm{e}$ & $\mathrm{h}$ \\
\hline J-TM3 & & $\mathrm{i}$ & 1 & f & $\mathrm{j}$ \\
\hline $\mathrm{J}-\mathrm{PN} 33$ & XVII & $\mathrm{i}$ & 1 & f & $\mathrm{j}$ \\
\hline J-YG38 & & $\mathrm{i}$ & 1 & f & $\mathrm{j}$ \\
\hline J-JKT25 & & $\mathrm{i}$ & 1 & f & $\mathrm{j}$ \\
\hline J-BGR15 & XVIII & o & 1 & $\mathrm{f}$ & $\mathrm{j}$ \\
\hline J-CTM20 & & o & 1 & f & $\mathrm{j}$ \\
\hline S-ST123 & XIX & 1 & o & g & $\mathrm{k}$ \\
\hline S-ST219 & $\mathrm{XX}$ & $\mathrm{m}$ & $\mathrm{p}$ & $\mathrm{h}$ & 1 \\
\hline S-ST325 & XXI & $\mathrm{n}$ & $\mathrm{k}$ & $\mathrm{b}$ & o \\
\hline J-MJ4 & XXII & $\mathrm{j}$ & $\mathrm{m}$ & $\mathrm{c}$ & g \\
\hline S-ST316 & XXIII & $\mathrm{k}$ & d & $\mathrm{a}$ & $\mathrm{n}$ \\
\hline S-BT221 & XXIV & $\mathrm{p}$ & $\mathrm{r}$ & $\mathrm{i}$ & q \\
\hline S-BT322 & XXV & $q$ & $\mathrm{~s}$ & $\mathrm{j}$ & $\mathrm{r}$ \\
\hline J-MJ28 & XXVI & $\mathrm{r}$ & $\mathrm{t}$ & $\mathrm{k}$ & $\mathrm{c}$ \\
\hline J-MJ47 & XXVII & $\mathrm{s}$ & $\mathrm{u}$ & $\mathrm{e}$ & $\mathrm{e}$ \\
\hline
\end{tabular}

*Letters represent the pattern of cut DNA that is presented as a finger-prints. Isolates with similar letter are classified in one group within their associated restriction enzymes.

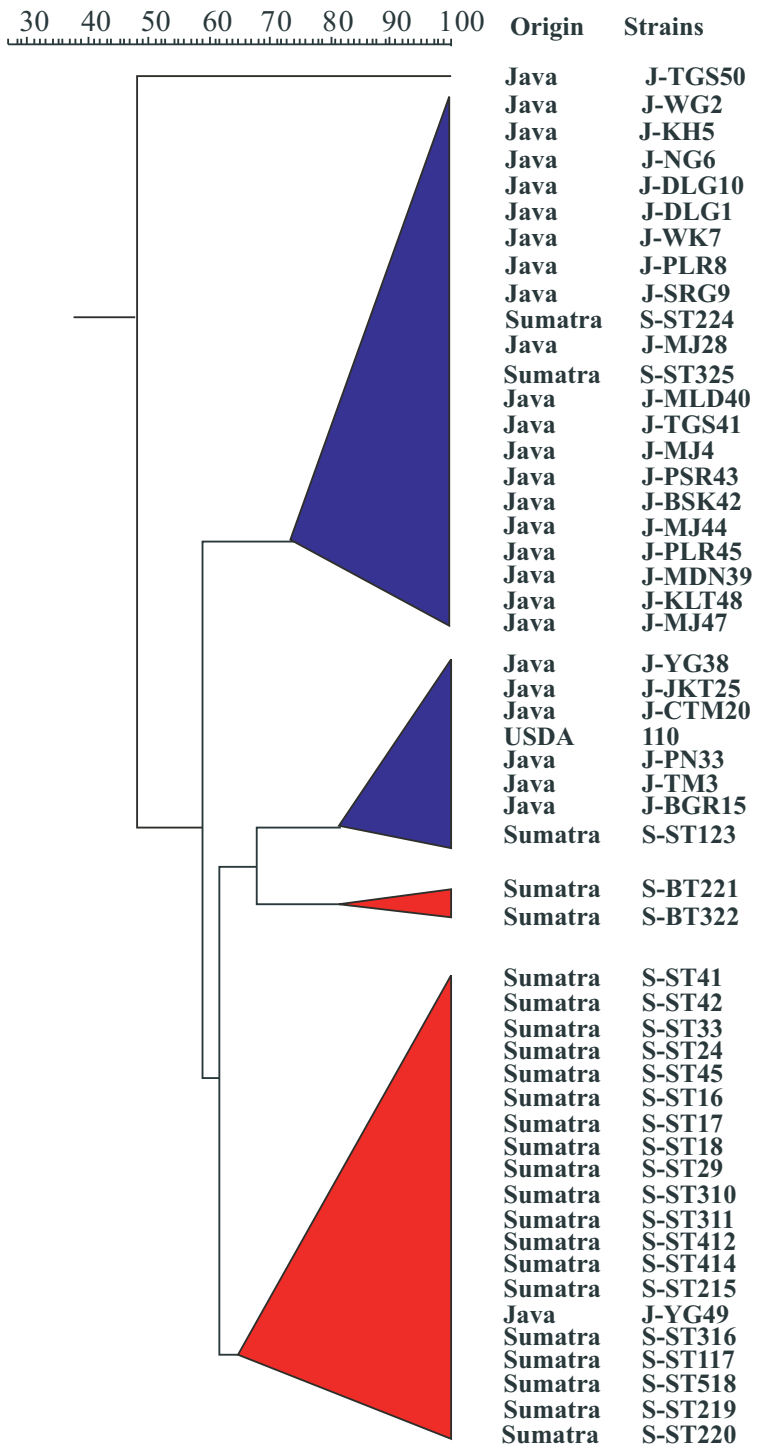

Fig 7 Dendogram derived from 16S-23S intergenic spacer ARDRA fingerprints of soybean rhizobial strains isolated from Java and Sumatra soil samples as well as Bradyrhizobium japonicum USDA 110. 
Table 2 Numbers of nucleotide differences and \% 16S rDNA homologies in the aligned sequences of well-known soybean-nodulating strains Bradyrhizobium elkanii (accession number BEU3500), Bradyrhizobium japonicum USDA 110 (accession number Z35330) and Sinorhizobium fredii USDA 205 (accession number D14516)

\begin{tabular}{|c|c|c|c|c|c|c|c|c|c|c|c|}
\hline \multirow[b]{2}{*}{ Strain } & \multicolumn{4}{|c|}{$\begin{array}{l}\text { B. elkanii } \\
\text { USDA76 }\end{array}$} & \multicolumn{4}{|c|}{$\begin{array}{l}\text { B. japonicum } \\
\text { USDA } 110\end{array}$} & \multicolumn{3}{|c|}{$\begin{array}{l}\text { S. fredii } \\
\text { USDA } 205\end{array}$} \\
\hline & $\begin{array}{l}\text { Number of } \\
\text { nucleotides }\end{array}$ & $\Delta \mathrm{N}^{1}$ & $\% \mathrm{H}^{2}$ & Strain & $\begin{array}{l}\text { Number of } \\
\text { nucleotides }\end{array}$ & $\Delta \mathrm{N}$ & $\% \mathrm{H}$ & Strain & $\begin{array}{l}\text { Number of } \\
\text { nucleotides }\end{array}$ & $\Delta \mathrm{N}$ & $\% \mathrm{H}$ \\
\hline S-ST17 & 1390 & 6 & 99.6 & J-WG2 & 1089 & 7 & 99.4 & J-TGS50 & 1440 & 30 & 97.9 \\
\hline S-ST414 & 1415 & 3 & 99.8 & J-DLG10 & 1265 & 28 & 97.8 & & & & \\
\hline J-KH5 & 1199 & 11 & 99.1 & J-SRG9 & 1443 & 15 & 99.0 & & & & \\
\hline J-Y49 & 1445 & 7 & 99.5 & J-TM3 & 1426 & 3 & 99.8 & & & & \\
\hline S-ST316 & 1443 & 9 & 99.4 & S-ST123 & 1329 & 23 & 98.3 & & & & \\
\hline S-ST29 & 1054 & 9 & 99.1 & S-ST325 & 1445 & 11 & 99.2 & & & & \\
\hline S-ST33 & 1442 & 10 & 99.3 & S-BT221 & 1447 & 21 & 98.5 & & & & \\
\hline S-ST215 & 1348 & 3 & 99.8 & S-BT322 & 1446 & 16 & 98.9 & & & & \\
\hline S-ST16 & 1446 & 25 & 98.3 & & & & & & & & \\
\hline S-ST518 & 1425 & 18 & 98.7 & & & & & & & & \\
\hline S-ST45 & 1360 & 6 & 99.6 & & & & & & & & \\
\hline S-ST117 & 1445 & 9 & 99.4 & & & & & & & & \\
\hline
\end{tabular}

${ }^{1}$ Number of nucleotide differences. ${ }^{2} \%$ of $16 \mathrm{~S}$ rDNA homology.
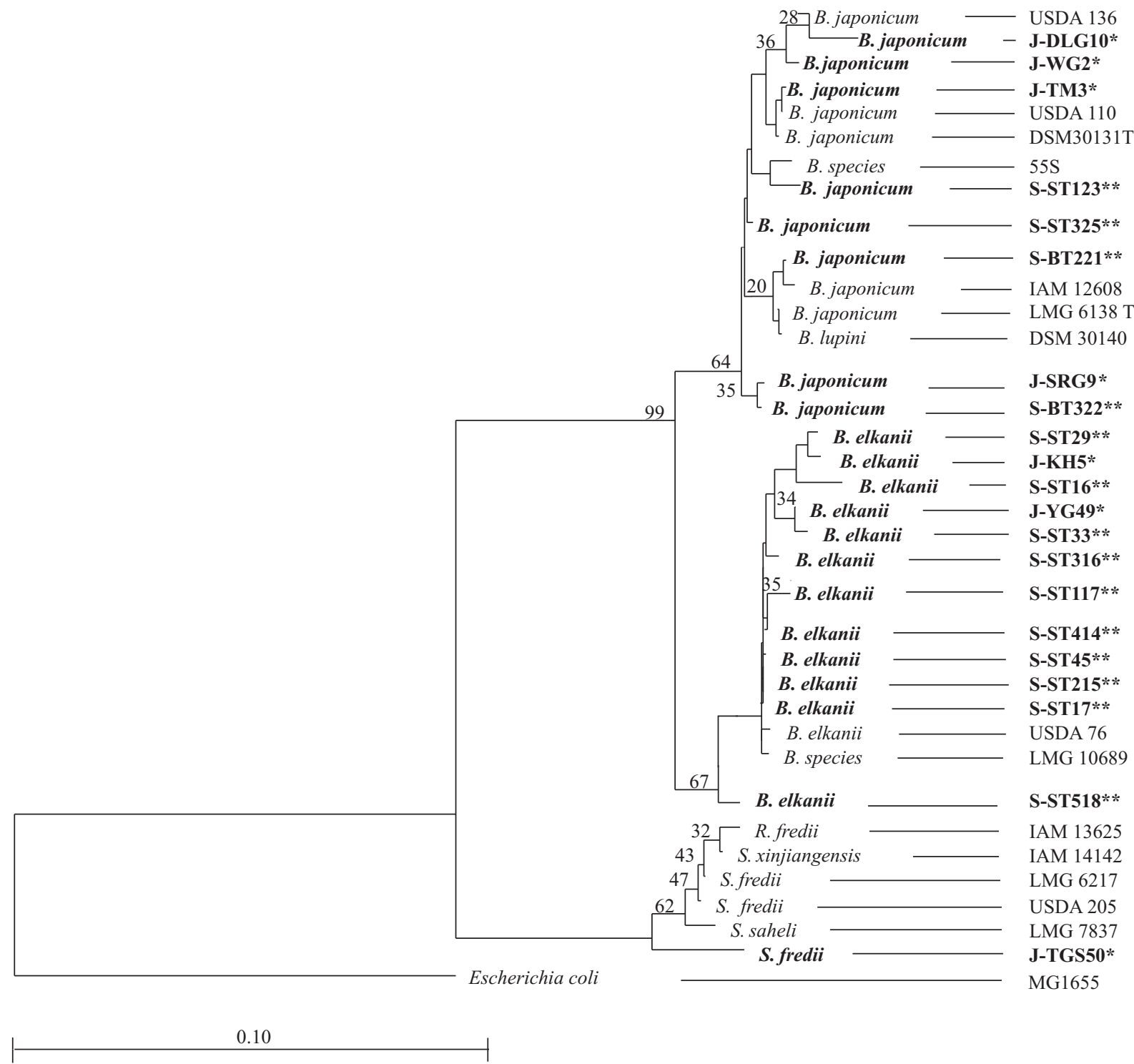

Fig 8 A rooted phylogenetic tree based on 16S rDNA sequences of the Indonesian rhizobial isolates (bold, * from Java and ** from Sumatra) and related other Bradyrhizobium and Sinorhizobium spp. constructed by the ARB Software with 100 times bootstrap. The bar indicates the phylogenetic distance (0.1 knuc). 
Table 3 Efficiency of rhizobial strains isolated from Java and Sumatra compared to reference strains. Number and weight of nodules formed on soybean as well as shoot weight were determined

\begin{tabular}{|c|c|c|c|c|}
\hline \multirow{2}{*}{ Strain } & & \multicolumn{2}{|c|}{ Nodule plant ${ }^{-1}$} & \multirow{2}{*}{$\begin{array}{l}\text { Shoot Weight } \\
\left(\text { g plant }^{-1}\right)\end{array}$} \\
\hline & & Number & Weight (g) & \\
\hline None & Control & 0 & 0 & $0.57 \pm 0.32$ \\
\hline Bradyrhizobium spp. ${ }^{@}$ & CB756 & 0 & 0 & $0.30 \pm 0.03$ \\
\hline Bradyrhizobium japonicum ${ }^{@}$ & USDA 110 & $43 \pm 10$ & $0.288 \pm 0.07$ & $3.36 \pm 0.80$ \\
\hline Bradyrhizobium japonicum $^{@}$ & CB1809 & $29 \pm 5$ & $0.250 \pm 0.06$ & $3.70 \pm 0.28$ \\
\hline Java@@ & & $46 \pm 10 \mathrm{a}^{*}$ & $0.263 \pm 0.07 \mathrm{a}^{* *}$ & $3.75 \pm 0.62 \mathrm{a} * * *$ \\
\hline \multirow[t]{2}{*}{ Sumatra@@ } & & $37 \pm 14 \mathrm{~b}$ & $0.225 \pm 0.07 \mathrm{~b}$ & $2.43 \pm 0.80 \mathrm{~b}$ \\
\hline & & $\mathrm{CV}^{\#}=33 \%$ & $\mathrm{CV}=29 \%$ & $\mathrm{CV}=25 \%$ \\
\hline
\end{tabular}

${ }^{\circledR}$ For these reference strains means were calculated from 3 replicates. ${ }^{@}$ A total of 24 randomly choosen bacterial strains used for each set of soil samples. *,**, $* * *$ Values followed by a different letter in same column are statistically different, revealed by T-test with confidence levels at $=0.10,0.05$ and 0.01 respectively. ${ }^{\#} \mathrm{CV}=$ Coefficient Variation (MSTAT-C, 1988)

\section{DISCUSSION}

Fifty-one different rhizobial strains (27 from Java and 24 from Sumatra) were isolated from nodules. Based on their nodulation ability on both soybean and mungbean, these rhizobial strains could be classified as promiscuous strains (34) or strains that show a narrow host-range (17) and only nodulate soybean (Fig. 2). Saono (1988) suggested that the native soybeanrhizobia population in Java appears to be dominated by promiscuous strains, and this is supported here with quantitative data. All of the soybean plants that were inoculated by rhizobial isolates from Java (except J-MJ44) grew vigorously in an $\mathrm{N}$-free medium. In contrast, several ineffective bradyrhizobial strains were found in Sumatra. It is likely that the abundance of these strains would have a negative impact on the inoculation by effective Bradyrhizobium spp. inoculants.

ARDRA of PCR-amplified 16S rDNA and 16S-23S rDNA spacer fragments were used to differentiate soybean-nodulating rhizobial strains. Based on ARDRA of 16S rDNA, nearly all of the soybeannodulating bacteria could be grouped into two separate large clusters comprising either the Java or the Sumatra isolates. ARDRA of 16S-23S rDNA spacer fragments has been reported to be useful for a further subclassification of bacteria (Jensen et al. 1993; MasolDeya et al. 1995; Gurtler and Stanisich 1996; Scheinert et al. 1996). This is due to the fact that the 16S-23S rDNA spacer region of all prokaryotes exhibit a high degree of sequence and size variations at the level of the genus and species. The sequence variations of the $16 \mathrm{~S}-23 \mathrm{~S}$ rDNA spacer region of the soybeannodulating bacteria confirmed the clustering of most Sumatra isolates and allowed a further classification of the Java isolates into two large distinct clusters. One of these clusters was found to include strains that were closely related to $B$. japonicum USDA 110 , a reference strain which is highly specific for soybean. Based on their grouping and symbiotic properties, we assume that these Java isolates and one isolate from Sumatra (S-ST123) are B. japonicum strains. Although clustered at one group, the isolate S-ST123 is distinct in its symbiotic property to $B$. japonicum USDA 110 . It formed many but ineffective soybean-nodules. One unique isolate from Java, J-TGS50, showed an unique position in comparison with the clustered isolates from Java and Sumatra. This group and the group containing most Sumatra isolates, which were also shown distinct from B. japonicum USDA 110, nodulated both soybean and the indigeneous mungbean. Hence these strains may represent the indigeneous bacterial population capable of nodulating soybean.

B. elkanii was found to be dominant in acid soils from Sitiung, West-Sumatra. Ten out of fourteen studied isolates from this location could be assigned to B. elkanii. Apart from isolate S-ST518 they form a homogeneous group, and notably strains S-ST17, SST45, S-ST117, S-ST215 and S-ST414 show high similarity to the reference strain B. elkanii USDA 76 (Fig 5). However in spite of their phylogenetic relation, the strains showed considerable variability in their symbiotic properties.

Only two out of seven strains from Java (strain J$\mathrm{KH} 5$ and J-YG49) were found to be B. elkanii. In contrast to the B. elkanii isolates from Sumatra, the N fixation capacity of these B. elkanii strains from Java was all very high on soybean.

B. japonicum was found dominant in Java. Four isolates (J-DLG10; J-WG2; J-TM3; J-SRG9) from seven analysed strains could be classified as $B$. 
japonicum. This confirms earlier results based on symbiotic properties and ARDRA 16S rDNA and 16S23S rDNA. One of these isolates, strain J-TM3, was very specific and effective on soybean. This could be due to the cultivation of imported soybean seeds contaminated with soils (Toxopeus 1938) or the introduction as inoculant by researchers (Newton 1962). It is not be possible to differentiate between these or other possibilities, but the observation that strain J-TM3 is highly related to $B$ japonicum USDA 110, a well known inoculant isolated from Japan, suggests strongly that it is not a native strain (Fig 2/Table 1). Remarkably, the other strains (J-DLG10; JWG2 and J-SRG9) have been shown to nodulate mungbean plants. This is in apparent contrast with the common phenotype of $B$. japonicum which is known to nodulate only soybean. Several B. japonicum strains (S-ST123; S-ST325; S-BT221; S-BT322) were also found in Sumatra soils. However, while all strains from Java are highly effective, these $B$. japonicum strains from Sumatra are ineffective.

It is interesting to note that a strain belonging to the genus Sinorhizobium that include fast growing species, was also found in Indonesia. Hence, the growth properties of this strain, J-TGS50, was determined and compared to the other $S$. fredii strains and B. japonicum USDA 110. Mean generation time (g) of J-TGS50 was almost 6-fold lower than that of B. japonicum USDA 110 and even lower than that previously reported for $S$. fredii. This was also apparent during growth of colonies on YEM agar plates. While colonies of the strain J-TGS50 with a diameter size between 0.10 - 1.0 mm could already be observed 3 days after inoculation, no USDA 110 colonies were detectable at the same period of time. Analysis of $16 \mathrm{~S}$ rDNA sequences of strain J-TGS50 showed it to be related to $S$. saheli and $S$. fredii. Until now, only $S$. fredii and not $S$. saheli strains have been reported to nodulate soybean (Keyser et al. 1982; De Lajudie et al. 1994; Young 1996). However, S. fredii strains were found to show a broad host-range and formed nodules on soybean as well as many other legumes, including cowpea, pigeon pea and mungbean (Scholla and Elkan 1984; Stowers and Eaglesham 1984; Chamber and Iruthayathas 1988). This contrasts with the restricted nodulation properties of strain J-TGS50 which did not nodulate mungbean.

From the data presented here and the earlier results, it can be concluded that there is no relationship between the nodulation phenotype and rRNA traits. This confirms earlier reports for BTAi1, a phototrophic symbiont of the legume Aeschynomene (Young et al. 1991) and for peanut bradyrhizobial strains (Zhang et al. 1999). Therefore, besides nodulation phenotype, other traits, eg. 16S rDNA sequences, should be taken into account for identification and classification of rhizobial strains.

This study demonstrates that species known to nodulate soybean, $B$. japonicum, $B$. elkanii and most likely also $S$. fredii are present in Indonesia. There appeared a great diversity in effectiveness between these brady- and sinorhizobia strains. In Java, many effective strains are already present in the soil, presumably by selection of soybean over a long period of cultivation. This could be the reason for the absence of a response to soybean inoculation practice in Java (Saono 1988).

Bradyrhizobia strains are present in low amount in acid soils of Sumatra and are suggested to occupy niches in the acid soils, which are not toxic to these bacteria. It is interesting that there is a large variation in $\mathrm{N}$ fixation capacity among the isolates from Sumatra. Hence, combination of $16 \mathrm{~S}$ rDNA sequence analysis as described here with nodulation phenotype trait analysis opens the possibility to select for elite, effective strain, adapted to acid soils. These strains may be used as inoculants for other transmigration areas in Indonesia, where poor acid soils are usually predominant.

\section{REFERENCES}

Beijerinck MW. 1888. Die bacterien der Papilionaceenknollchen. Bot. Zgt. $46: 726-735$.

Chamber MA, Iruthayathas EE. 1988. Nodulation and nitrogen fixation by fast- and slow growing rhizobia strains of soybean on several temperate and tropical legumes. Plant Soil 112: 239-245.

Chen WX,Wang ET, Wang SY, Li YB, Gao JL, Chen XQ, Li Y. 1995. Characteristics of Rhizobium tianshanense sp. nov., a moderately and slowly growing root nodule bacterium isolated from an arid saline environment in Xinjiang, People's Republic of China. Int J Syst Bacteriol. 45: 153-159.

de Lajudie P, Willems A, Pot B, Dewettinck D, Maestrojuan G, Neyra M, Collins M D, Dreyfus B, Kersters K , Gillis M. 1994. Polyphasic taxonomy of rhizobia: Emendation of the genus Sinorhizobium and description of Sinorhizobium meliloti comb. nov., Sinorhizobium saheli sp. nov., and Sinorhizobium teranga sp. nov. Int J Syst Bacteriol. 44: 715-733

El-Fiki AA. 2006. Genetic diversity in rhizobia determined by random amplified polymorphic DNA analysis. JAgric Soc Sci. 2(1): 1-4.

Graham PH, Sadowsky MJ, Keyser HH, Barnet YM, Bradley RS, Cooper JE, De Ley DJ, Jarvis BDW, Roslycky EB, Strijdom BW, Young JPW. 1991. Proposed minimal standards for the description of new genera and species of root- and stem-nodulating bacteria. Int J Syst Bacteriol. 41(4): 582-587.

Gurtler V, Stanisich VA.1996. New approaches to typing and identification of bacteria using the $16 \mathrm{~S}-23 \mathrm{~S}$ rDNA spacer region. Microbiology 142: 3-16.

Hymowitz T, Newell CA.1981. Taxonomy, specification, domestication, dissemination, germplasm resources and variation in the genus Glycine. In: Summerfield RJ, Bunting AH, editors. Advance in legume science Royal Botanic Gardens, Kew, United Kingdom. p 251-264.

Hungria M, Chueire LMO, Megias M, Lamrabet Y, Probanza A, GuttierrezManero FJ, Campo RJ. 2006. Genetic diversity of indigenous tropical fast-growing rhizobia isolated from soybean nodules. Plant Soil 288: 343-356. doi: 10.1007/s11104-006-9125-0. 
Jarvis BDW, Van Berkum P, Chen W X, Nour S M, Fernandez M P, CleyetMarel J C, Gillis M. 1997. Transfer of Rhizobium loti, Rhizobium huakuii, Rhizobium ciceri, Rhizobium mediterraneum, and Rhizobium tianshanense to Mesorhizobium gen. nov. Int J Syst Bacteriol. 47: 895898.

Jensen M A, Webster J A, Straus N. 1993. Rapid identification of bacteria on the basis of polymerase chain reaction-amplified ribosomal DNA spacer polymorphisms. Appl Environ Microbiol. 59: 945-952.

Keyser H H, Ben Bohlool B, Hu T S, Weber DF. 1982. Fast-growing rhizobia isolated from root nodules of soybean. Science 215: 16311632.

Kwon SW, Park JY, Kim JS, Kang JW, Cho YH, Lim CK, Parker MA, Lee GB. 2005. Phylogenetic analysis of the genera Bradyrhizobium, Mesorhizobium, Rhizobium and internally transcribed spacer region sequences. Int J Syst Evolution Microbiol. 55: 263-270. doi: 10.1099/ijs.0.63097-0.

Laguerre G, Allard M, Revoy F, Amarger N. 1994. Rapid identification of rhizobia by restriction fragment length polymorphism analysis of PCR-amplified 16S rRNA genes. Appl Environ Microbiol. 60: 56-63.

Lane D J. 1991. 16S/23S rRNA sequencing. In: Stackebrandt E and Goodfellow $M$, editors. Nucleic acid techniques in bacterial systematics. Chichester: John Willey \& Sons Pr. p 115-175.

Lu J, Kang L, He X, Xu D. 2011. Multilocus sequence analysis of the Rhizobia from five woody legumes in southern China. Afri J Microbiol Res. 5(30): 5343-5353.

Martens M, Delaere M, Coopman R, De Vos P, Gillis M, Willems A. 2007.Multilocus sequence analysis of Ensifer and related taxa. Int J Syst Evol Microbial. 57: 489-503. doi: 10/ijs.0.64344-0.

Massol-Deya AA, Odelson DA, Hickey RF, Tiedje JM. 1995. Bacterial community fingerprinting of amplified $16 \mathrm{~S}$ and 16-23S ribosomal DNA gene sequences and restriction endonuclease analysis (ARDRA). Section 3: Identification and classification of microbes using DNA and RNA sequences. In: Akkermans A D L, van Elsas J D, De Bruijn F J, editors. Molecular microbial ecology mannual. Dordrecht: Kluwer Academic Pr.p 3.3.2/1-3.3.2/8.

Newton JD .1962. Soil fertility and legume inoculation investigation in Indonesia. Report to the government of Indonesia. FAO No. 1541. FAO and Agriculture Organization of the United Nations. Rome, Italy.

Novikova NI .1996. Modern concepts of the phylogeny and taxonomy of nodule bacteria. Microbiology 65:383-394.

Raychaudhuri S, Yadav AK, Raychaudhuri M. 2007. Changing face of rhizobial taxonomy. Biofertiliser Newsletter 15(1): 3-14.

Rademaker JLW, De Bruijn FJ. 1997. Characterization and classification of microbes by REP-PCR genomic fingerprinting and computer-assisted pattern analysis. In: Caetano-Annoles G, Gresshoff PM, editors. DNA markers: Protocols, applications and overviews. New York:J.Wiley \& Sons Pr. p 151-171.

Rivas R, Garcia-Fraile P, Velazquez E. 2009. Taxonomy of bacteria nodulating legumes. Rev Microbiol Insight. 2: 51-69.
Saono S .1988. Biological nitrogen fixation in food legumes. BNFWG Country Report Indonesia. Proceedings second working group meeting and workshop. FAO/UNDP Project RAS/82/002. Chiang Mai, Thailand. p17-33.

Scheinert P, Krausse R, Ullmann U, Soller R, Krupp G .1996. Molecular differentiation of bacteria by PCR amplification of the 16S-23S rRNA spacer. J Microbiol Method. 26: 103-117.

Scholla MH, Elkan GH .1984. Rhizobium fredii sp.nov., a fast-growing species that effectively nodulates soybeans. Int J Syst Bacteriol. 34: 484-486.

Sikora S, Redzepovic S. 2003. Genotypic characterisation of indigenous soybean rhizobia by PCR-FLFP of $16 \mathrm{~S}$ rDNA, rep-PCR and RAPD analysis. Food Technol Biotechnol. 41(1): 61-67.

Somasegaran P, Hoben HJ .1995. Handbook for rhizobia. methods in legume-Rhizobium technology. Springer-Verlag. New York, Inc., New York, United States of America.

Stowers MD, Eaglesham ARJ .1984. Physiological and symbiotic characteristics of fast-growing Rhizobium japonicum. Plant Soil 77: 314.

Toxopeus HJ. 1938. Over het voorkomen van de knolletjesbacterien van kedelee (sojaboon) in verband met de wenschelijkheid van enten van het zaaizaad ( Spreading of soybean-nodulating bacteria due to trading of soybean seeds). Landbouw XIV. No. 4: $1-20$.

Vandamme P, Pot B, Gillis M, De Vos P, Kersters K, Swings J. 1996. Polyphasic taxonomy, a consensus approach to bacterial systematics. Microbiol Rev. 60 (2): 407-438.

Willems A. 2006. The taxonomy of rhizobia : an overview. Plant Soil 287: 314. doi: 10.1007/s11104-006-9058-7.

Winarno R, Lie TA.1979. Competition between rhizobium strains in nodule formation : Interaction between nodulating and non-nodulating strains. Plant Soil 51: 135-142.

Young JPW, Downer HL, Eardly BD .1991. Phylogeny of the phototropic Rhizobium strain BTAil by polymerase chain reactions-based sequencing of a 16S rRNA gene segment. J Bacteriol. 173: 2271-2277.

Young J PW .1996. Phylogeny and taxonomy of rhizobia. Plant Soil 186: 45-52.

Young JM. 2003. The genus name Ensifer Casida 1982 takes priority over Sinorhizobium Chen et al. 1988, and Sinorhizobium morelense Wang et al. 2002 is a later synonym of Ensifer adhaerens Casida 1982. Is the combination 'Sinorhizobium adhaerens' (Casida 1982) Willems et al. 2003 legitimate? Request for an opinion. Int J Syst Evol Microb. 53: 2107-2110.

Young JM. 2010. Sinorhizobium versus Ensifer: may a taxonomy subcommittee of the ICSP contradict the Judicial Commission? Int $\mathbf{J}$ Syst Evol Microb. 60: 1711-1733.

Zhang A, Nick G, Kaijalainen S, Terefework Z, Paulin L, Tighe SW, Graham PH, Lindstrom K .1999. Phylogeny and diversity of Bradyrhizobium strains isolated from root nodules of peanut (Arachis hypogaea) in Sichuan, China. System Appl Microbiol. 22: 378-386. 